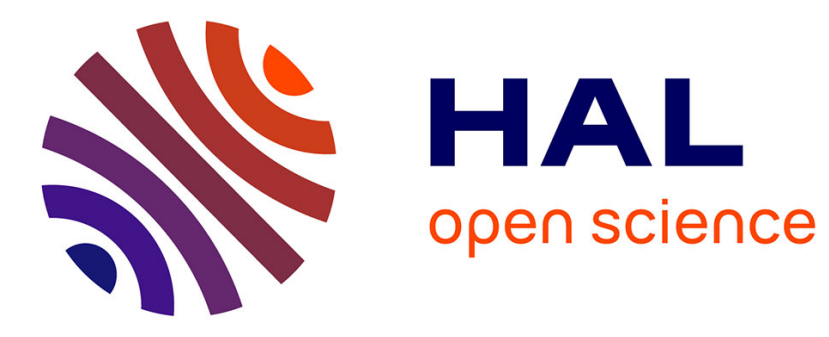

\title{
Cancer immune contexture and immunotherapy
}

Etienne Becht, Nicolas A Giraldo, Marie-Caroline Dieu-Nosjean, Catherine Sautès-Fridman, Wolf Herman Fridman

\section{To cite this version:}

Etienne Becht, Nicolas A Giraldo, Marie-Caroline Dieu-Nosjean, Catherine Sautès-Fridman, Wolf Herman Fridman. Cancer immune contexture and immunotherapy. Current Opinion in Immunology, 2016, 39, pp.7-13. 10.1016/j.coi.2015.11.009 . hal-01281664

\section{HAL Id: hal-01281664 https: / hal.sorbonne-universite.fr/hal-01281664}

Submitted on 2 Mar 2016

HAL is a multi-disciplinary open access archive for the deposit and dissemination of scientific research documents, whether they are published or not. The documents may come from teaching and research institutions in France or abroad, or from public or private research centers.
L'archive ouverte pluridisciplinaire HAL, est destinée au dépôt et à la diffusion de documents scientifiques de niveau recherche, publiés ou non, émanant des établissements d'enseignement et de recherche français ou étrangers, des laboratoires publics ou privés. 


\section{Cancer immune contexture and immunotherapy}

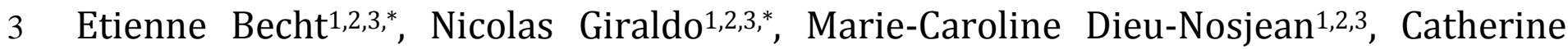
4 Sautès-Fridman ${ }^{1,2,3}$, Wolf Herman Fridman ${ }^{1,2,3}$

$5{ }^{1}$ INSERM UMR_S 1138, Cancer, Immune Control and Escape, Cordeliers Research Centre, Paris, France

$6 \quad{ }^{2}$ Université Paris Descartes, Paris, France

$7 \quad{ }^{3}$ Université Pierre et Marie Curie, Paris, France

$8 \quad$ *These authors contributed equally to this work 
The immune contexture characterizes the clinical impact of the density, the location, the organization and the functional orientation of tumor-infiltrating immune cells in cancers. It is, in great part, shaped by the malignant cells, as in a given cancer type, tumors presenting different oncogenic processes have different immune contextures. Moreover, the immune contexture in metastatic sites reflects that of the corresponding primary tumors. Finally, the components forming the immune contexture represent targets and markers of efficient anti-cancer immunotherapies.

The immune contexture is a concept that emerged from studies mostly performed in human colorectal cancer (CRC). A comprehensive analysis of a large collection of primary CRC tumors revealed that a high density of intratumoral memory $\mathrm{T}$ cells correlates with patients' longer disease-free (DFS) and overall (OS) survivals [2], confirming a previous report in ovarian cancer [3]. A closer histopathological analysis of CRC tumors highlighted the fact that the $\mathrm{T}$ cells were not stochastically distributed within the tumor microenvironment but were present in the center (CT) and the invasive margin (IM) of the tumor nests [4]. The densities of memory CD8 ${ }^{+} \mathrm{T}$ cells in both the CT and the IM were associated with favorable prognosis, as well as the expression of genes encoding Th1 cytokines (IFN- $\gamma$, IL2) and cytotoxic mediators (granzymes, granulysin)[4]. A comprehensive approach of all genes having any type of correlation with genes whose expression correlated with both clinical outcome and tumor infiltration by $\mathrm{T}$ cells predicted that certain chemokines (CXCL13, CXCL9, CXCL10) were involved in shaping an efficient immune microenvironment [5] and foster T cells activation [6].

In parallel to these studies in CRC, our group has investigated the immune microenvironment of Non-Small-Cell-Lung Cancer (NSCLC). In addition to confirming the beneficial effect of high densities of T cells with a Th1 orientation and of cytotoxic $\mathrm{CD}^{+} \mathrm{T}$ cells, these studies revealed the essential role of tumor-associated Tertiary Lymphoid Structures (TLS), lymphoid aggregates that structurally resemble secondary lymphoid organs [7][8]. These formations are present in the invasive margin and in the 
stroma of lung tumors and absent in distant non-tumoral lung tissue. They are organized in a T-cell and a B-cell zone surrounded by High Endothelial Venules (HEV). $\mathrm{T}$ cells are in contact with mature $\mathrm{DC}$, and $\mathrm{B}$ cells with follicular dendritic cells (FDC) and tingible-body macrophages. B cells express the activation-induced deaminase (AID) enzyme necessary for somatic hypermutation and immunoglobulin isotype switching, a marker of active germinal center (GC) [9]. These data led us to hypothesize that TLS are sites where immune reactions toward tumor-associated antigens are generated [10]. Since they are exclusively present within TLS, naïve T and B cells may have emigrated from peripheral blood via HEV. Thus, TLS may represent an immuneprivileged site where naïve lymphocytes may be protected from the immunosuppressive and inflammatory milieu of the tumor during their differentiation phase. Indeed, high density of these tumor-associated TLS positively correlates with NSCLC patient's prognosis [8][9][7]. This is in accordance with the fact that HEV are the only type of blood vessels which positively correlates with favorable clinical outcome of cancer [11]. TLS-infiltrating naive B cells differentiate into memory B cells and plasma cells which produce anti-tumor antibodies [9]. T cells in TLS are educated by antigenpresenting DC, become memory lymphocytes and migrate into other tumor areas, resulting in local control, and to peripheral lymph nodes where they restrain metastatic spread[10]. TLS likely influence the functional orientation of tumor-infiltrating $\mathrm{T}$ cells, as intratumor T cells have a Th1 and cytotoxic CD8 orientation in tumors having high TLS densities [8].

These initial observations in CRC and NSCLC have been extended to most cancer types [1][10]. Indeed the evaluation of the immune contexture involves quantitative immunohistochemistry and gene expression techniques (for evaluation of $\mathrm{Th}$ orientation for instance) and both type of assays needs expertise to be performed successfully. Regarding $\mathrm{T}$ cell infiltration, an "Immunoscore" has been defined quantifying by immunochemistry two out of the three markers, CD3, CD8 and CD45RO, in the invasive margin and the center of tumors[12]. A general trend emerges that high densities of memory T cells with a Th1 orientation and $\mathrm{CD}^{+}$phenotype correlate with longer DFS and OS also in ovarian, bladder, breast, prostatic, head and neck, and cervical cancers, hepatocellular carcinoma and melanoma (reviewed in [1] and [13]).

Regarding TLS or Ectopic Lymphoid Structures, their quantification has been performed using the DC-Lamp marker, lymphoid aggregates in HES sections, CD20 positive follicles or PNAd+ marker for HEV. Whatever the methodology used, the data show that high densities of TLS also correlate with favorable clinical outcome in CRC, breast, gastric, pancreatic, colorectal and renal cancers, oral squamous carcinoma, Merkel cell carcinoma, Warthin tumor as well as melanoma (reviewed in [10]). These studies establish the immune contexture as a well-studied, robust and clinically relevant characteristic of human cancers biology.

However T and B lymphocytes, and TLS are far from being the only components of the immune and inflammatory microenvironment of tumors. The densities and organization of these other cell types also influence patient's clinical outcome although with less significant power. Indeed the identification of some cell subpopulations such 
as Treg[14] or MDSC can be hampered by the lack of consensus markers. Howewer, a trend emerges that high densities of myeloid cells, such as macrophages, MDSCs and mast cells, and particularly M2 macrophages are associated with poor prognosis[13][15][16][17][18]. NK cells infiltrating tumors can be anergic[19][20]. Extensive NK cells infiltration has nonetheless usually been associated with favorable patient outcome[6][21][22][23].

Regarding the other $\mathrm{T}$ cell subsets, their impact may depend on the cancer type. It is the case for Th2, $\mathrm{T}_{\text {reg }}$ or Th17 (reviewed in [1]). High densities of DC, $\mathrm{T}_{\mathrm{FH}}$ and B cells in TLS correlate with favorable prognosis[6]. In presence of low or no TLS, high densities of stromal B cells, CD8 ${ }^{+} \mathrm{T}$ cells and DC are associated with poor prognosis, and may support pro-tumoral inflammation and $\mathrm{T}$ cell anergy, underlining again the importance of the location of the immune cells in the tumor landscape [8].

Despite the general agreement on the favorable prognostic value of the density of Th1 and CD8 ${ }^{+}$T cells, discordant results have been reported in clear cell RCC (ccRCC) [24], Hodgkin lymphoma [25] or uveal melanoma [26]. Intrigued by these results, we recently analyzed a cohort of primary ccRCC and confirmed that high densities of CD8+ $\mathrm{T}$ cells in the IM correlated with shorter DFS and OS [27]. Even more intriguingly, high expression of the IFN- $\gamma$, TBX21, and granzyme-B genes were a highly significant marker of poor prognosis [27]. These results prompted us to study the immune contexture of ccRCC. We found that there were few TLS in most ccRCC tumors [28][10]. Most CD8 ${ }^{+} \mathrm{T}$ cells presented an exhausted phenotype with concomitant expression of LAG3 and PD1 , and tumor cells expressed PD-1 ligands [27]. Patients with tumors containing high densities of PD-1+CD8+ T cells, and PD-L1 or PD-L2 expression by tumor cells had the worst prognosis. Strikingly, in most ccRCC tumors, immature DC-Lamp ${ }^{+}$DC were found outside TLS, close to blood vessels (and not to HEV). It is therefore likely that these DC instructed incoming $\mathrm{T}$ cells in an inflammatory and immunosuppressed milieu resulting in an abortive immune response. The IFN- $\gamma$ production by $\mathrm{T}$ cells has been reported to induce PD-L1 and/or PD-L2 on tumor cells [29], resulting in an exhaustion of the immune reaction. Indeed, in the few tumors with high densities of mature DC inside TLS, high CD8 ${ }^{+} \mathrm{T}$ cells density correlated with favorable prognosis, supporting the role of TLS in educating HEV-penetrating naive $\mathrm{T}$ cells to recognize tumorassociated antigens and to control cancer aggressiveness [27]. These data suggest that certain tumor types may be characterized by a disrupted immune contexture, most likely governed by the malignant cells.

\section{Clinical impact of the immune contexture in metastatic sites}

It is intuitively thought that tumor progression is accompanied by tumor escape from the immune system [30][31]. If this escape linearly followed cancer progression, the immune contexture of metastatic sites should not impact clinical outcome. However, high densities of $\mathrm{CD}^{+} \mathrm{T}$ cells in hepatic and lung metastases of CRC correlate with longer OS [28], as in primary CRC [4]. Densities of infiltrating immune cells were shown to be correlated between the primary tumors and matched metastases[28]. These 
findings both suggest that the malignant cells are prominent in shaping their immune microenvironments. This hypothesis is strengthened by the study of lung metastases of ccRCC. In contrast to lung metastases of CRC in which high TLS and CD8 ${ }^{+} \mathrm{T}$ cell densities correlate with favorable prognosis, lung metastases of ccRCC have few TLS, and high CD8 ${ }^{+} \mathrm{T}$ cell densities correlate with shorter OS, as in primary ccRCC[28]. In addition, transcriptomic analyses revealed a higher expression of genes involved in inflammation, immunosuppression and angiogenesis in lung metastases from ccRCC than in lung metastases from CRC, confirming differences in the functional orientations of these immune contextures[28].

\section{Clinical impact of the immune contexture within a given cancer}

Whole genome transcriptomic analyses provide a novel way to classify subgroups in a given cancer type. These unsupervised approaches complement genomic classifications by identifying malignant cell subgroups with distinct functional traits. We undertook an analysis of the expression of immune genes and the concomitant immune cell infiltration in cohorts of various human cancers. To precisely analyze the immune contexture of large collections of human cancers, we established transcriptomic signatures based on the specific expression of genes in a given hematopoietic subset. We identified robust immune metagenes for lymphocytes ( $\mathrm{T}$ and B cell subsets, NK, T $\gamma \delta$, cytotoxic cells), myeloid cells (macrophages, monocytes, granulocytes, DC) as well as endothelial cells and fibroblasts (EB submitted). These signatures were validated in vitro in mixtures of hematopoietic and tumor cells and ex-vivo on CRC tumor sections. They were completed by analyses of genes expressed modulating immune functions (cytokines, chemokines, MHC class I) that sign the functional orientation of the immune microenvironments. We review herein our data in two cancers, prototypic for the clinical impacts of their immune contextures, CRC and ccRCC.

Different molecular classifications have been proposed for CRC and merged in a foursubgroups consensus classification [32]. It identifies a microsatellite-instability (MSI)enriched group with good prognosis, a mesenchymal subgroup with the worst prognosis, and KRAS mutated and canonical subgroups with intermediate prognosis. We applied the immune signatures to these classifications. We analyzed three cohorts of CRC including over 2000 patients and found that molecular subgoups had distinct immune signatures. The hypermutated MSI-enriched subgroup had the highest infiltration of $\mathrm{T}$ cells along with cytotoxic lymphocytes, followed by the mesenchymal subgroup which also presented with high lymphocytic infiltration in the context of high myeloid cell infiltration as well as extensive presence of endothelial cells and fibroblasts [33]. The two other groups of tumors had very poor expression of the immune gene signatures. These analyses show that the malignant cells can influence the density of immune and inflammatory cells in tumors. The hypermutated MSIenriched group had the highest expression of genes involved in $\mathrm{T}$ cell chemotaxis (CXCL9, CXCL10, CXCL16), T cell activation (IFN- $\gamma$, IL15), T cell inhibition (PD-L1, PDL2, CTLA-4, LAG3), and TLS formation (CXCL13). The mesenchymal subgroup had the highest expression of genes involved in myeloid cell chemotaxis (CCL2), angiogenesis (VEGF, PDGF), immunosuppression (TGF $\beta$ ), and inflammation (CCL2, complement- 
related genes). The two immune low groups had also the lowest MHC Class I expression [33]. Taken together, these data support the concept that the MSI-tumors, which have defects in the DNA-repair enzymes, produce mutated neo-antigens that activate $\mathrm{T}$ cells, concurring to shape a favorable immune contexture. In contrast, the mesenchymal tumors, through a high production of angiogenic and inflammatory molecules shape a disrupted immune contexture where inflammation fuels tumor growth while $\mathrm{T}$ cells are attracted, but not properly educated towards tumor antigens, resulting in a poor clinical outcome. Finally, tumors from conventional precursors and with high activation of the Wnt pathway, down-regulate their MHC Class I molecules and escape the T cell attacks, which correlates with intermediate prognosis.

We also analyzed the immune signatures in ccRCC primary tumors from metastatic patients treated with Sunitinib, a tyrosine kinase inhibitor. Unsupervised transcriptomic analyses identified four molecular subgroups [34]. Patients of two subgroups responded well to Sunitinib treatment, and consistently had longer Progression-Free Survival (PFS) and OS. The patients of the two other subgroups poorly responded to Sunitinib treatment, and had the worst prognosis. The analyses of the immune signatures revealed that the worst prognostic group had the highest infiltration with lymphoid cells in the context of a high myeloid cell infiltration. Genes involved in T cell chemotaxis (CXCL9, CXCL10, CXCL13), Th1 orientation (IFN- $\gamma$, IL12, TBX21), T cell exhaustion (PD1, PD-L1, LAG3) and inflammation (TNF- $\alpha$, CSF1) were highly expressed. The other bad prognosis group had the highest NK cell infiltration and the lowest expression of genes related to adaptive immunity including MHC Class I [32].

Altogether, this analysis of two prototypic tumors showed that within each cancer type, an immunological classification identifies different subtypes of patients with different clinical outcomes corresponding to different oncogenic processes. Thus, we already identified three cancer types (Fig 1):

- the "immunogenic tumors" with production of immunogenic peptides, and an organized immune contexture that generates anti-tumor $\mathrm{T}$ cells and antibodies, resulting in a favorable prognosis,

- the "inflammatory tumors" with production of inflammatory, angiogenic and immunosuppressive molecules that disrupt the immune contexture and attract pro-tumor myeloid and lymphoid cells, resulting in exhausted tumor aggressiveness and poor patient's clinical outcome,

- the "escaping tumors" which down regulate their antigen-presenting machinery produce little or no chemokines and cytokines, and are blind to the immune attack. Patients with such tumors have an intermediate prognosis.

These classifications not only reveal pathological features of cancers but also offer targets and predictive markers for immunotherapies (Table 1).

\section{The immune contexture and response to therapy}


217 The immune microenvironment of tumors not only reflects the oncogenic processes of

218 a cancer in a patient, but is also a constitutive arm of cancer control and thus of patient's clinical outcome. It is therefore likely that therapeutic interventions modifying the immune contexture will result in profound changes in cancer evolution. Characterizing the immune contexture or the corresponding molecular profile of a tumor in a patient will allow clinicians to propose the most appropriate therapies. For instance, MSI CRC tumors with high mutational load respond to PD1 axis blockade [35]. Consistent results have been observed in NSCLC [36]. In melanoma patients treated with anti-PD-1 antibodies, responding tumors are characterized by the entry of preexisting CD8 ${ }^{+} \mathrm{T}$ cells from the IM to the CT[37], exemplifying the role of T cell location into tumors[4]. In cervical carcinoma [38] or pancreatic cancer [39], responses to therapeutic vaccination are accompanied by the increase of TLS in the tumor vicinity. In ccRCC patients responding to anti-PD-1 or anti-PD-L1 antibodies, tumors express both molecules on their infiltrating lymphocytes and tumor cells, respectively [40]. In bladder cancer, the expression of PD-L1 on infiltrating immune cells was found essential for response to this immunotherapy [41].

For immune silent tumors, bi-specific antibodies direct to tumor antigens may attract and activate $\mathrm{T}$ cells into responding tumors[42]. T cells-based therapies aim also to bring missing memory $\mathrm{T}$ cells into tumors. Strikingly, therapies with antibodies recognizing tumor-associated antigens, such as CD20 [43], or HER2-Neu [44], are capable of inducing a memory anti-tumor $\mathrm{T}$ cell response responsible for the long-term effect of these therapies. In tumors where class I MHC molecules are downregulated, autologous NK cells transfer, recombinant IL15 or KIR-blocking antibodies could foster NK cells activation and MHC-negative tumor cells elimination[45]. Finally, the immune microenvironment is implicated in the long lasting effects of chemotherapies and radiotherapies, by creating an appropriate microenvironment associated with the release of immunogenic molecules by the tumor cells. 


\section{References}

1. Fridman, W.H., Pagès, F., Sautès-Fridman, C. \& Galon, J.: The immune contexture in human tumours: impact on clinical outcome. Nat Rev Cancer 2012,12:298-306.

2. Pagès, F., Berger, A., Camus, M., Sanchez-Cabo, F., Costes, A., Molidor, R., Mlecnik, B., Kirilovsky, A., Nilsson, M., Damotte, D. et al.: Effector memory T cells, early metastasis, and survival in colorectal cancer. $N$ Engl J Med 2005,353:2654-2666.

3. Zhang, L., Conejo-Garcia, J.R., Katsaros, D., Gimotty, P.A., Massobrio, M., Regnani, G., Makrigiannakis, A., Gray, H., Schlienger, K., Liebman, M.N. et al.: Intratumoral T cells, recurrence, and survival in epithelial ovarian cancer. $N$ Engl $J$ Med 2003,348:203-213.

4. Galon, J., Costes, A., Sanchez-Cabo, F., Kirilovsky, A., Mlecnik, B., Lagorce-Pagès, C., Tosolini, M., Camus, M., Berger, A., Wind, P. et al.: Type, Density, and Location of Immune Cells Within Human Colorectal Tumors Predict Clinical Outcome. Science 2006,313:1960-1964.

5. Mlecnik, B., Tosolini, M., Charoentong, P., Kirilovsky, A., Bindea, G., Berger, A., Camus, M., Gillard, M., Bruneval, P., Fridman, W. et al.: Biomolecular network reconstruction identifies $\mathrm{T}$-cell homing factors associated with survival in colorectal cancer. Gastroenterology 2010,138:1429-1440.

6. Bindea, G., Mlecnik, B., Tosolini, M., Kirilovsky, A., Waldner, M., Obenauf, A.C., Angell, H., Fredriksen, T., Lafontaine, L., Berger, A. et al.: Spatiotemporal dynamics of intratumoral immune cells reveal the immune landscape in human cancer. Immunity 2013,39:782-795.

7. Dieu-Nosjean, M., Antoine, M., Danel, C., Heudes, D., Wislez, M., Poulot, V., Rabbe, N., Laurans, L., Tartour, E., de Chaisemartin, L. et al.: Long-term survival for patients with non-small-cell lung cancer with intratumoral lymphoid structures. J Clin Oncol 2008,26:4410-4417.

8. Goc, J., Germain, C., Vo-Bourgais, T.K.D., Lupo, A., Klein, C., Knockaert, S., de Chaisemartin, L., Ouakrim, H., Becht, E., Alifano, M. et al.: Dendritic cells in tumorassociated tertiary lymphoid structures signal a Th1 cytotoxic immune contexture and license the positive prognostic value of infiltrating CD8+ $T$ cells. Cancer Res 2014,74:705-715.

9. Germain, C., Gnjatic, S., Tamzalit, F., Knockaert, S., Remark, R., Goc, J., Lepelley, A., Becht, E., Katsahian, S., Bizouard, G. et al.: Presence of B cells in tertiary lymphoid structures is associated with a protective immunity in patients with lung cancer. Am J Respir Crit Care Med 2014,189:832-844. 
10. Dieu-Nosjean, M., Goc, J., Giraldo, N.A., Sautès-Fridman, C. \& Fridman, W.H.: Tertiary lymphoid structures in cancer and beyond. Trends Immunol 2014,35:571580.

11. Martinet, L., Garrido, I., Filleron, T., Le Guellec, S., Bellard, E., Fournie, J., Rochaix, P. \& Girard, J.: Human solid tumors contain high endothelial venules: association with $\mathrm{T}$ - and B-lymphocyte infiltration and favorable prognosis in breast cancer. Cancer Res 2011,71:5678-5687.

12. Becht, E., Giraldo, N.A., Germain, C., de Reyniès, A., Laurent-Puig, P., Zucman-Rossi, J., Dieu-Nosjean, M., Sautès-Fridman, C. \& Fridman, W.H.: Immune contexture, immunoscore and malignant cell molecular subgroups for prognostic and theranostic classifications of cancers. Advances in immunology In press,:.

13. Klein, J.L., Nguyen, T.T., Bien-Willner, G.A., Chen, L., Foyil, K.V., Bartlett, N.L., Duncavage, E.J., Hassan, A., Frater, J.L. \& Kreisel, F.: CD163 immunohistochemistry is superior to CD68 in predicting outcome in classical Hodgkin lymphoma. Am J Clin Pathol 2014,141:381-387.

14. Jensen, T.O., Schmidt, H., Møller, H.J., Høyer, M., Maniecki, M.B., Sjoegren, P., Christensen, I.J. \& Steiniche, T.: Macrophage markers in serum and tumor have prognostic impact in American Joint Committee on Cancer stage I/II melanoma. J Clin Oncol 2009,27:3330-3337.

15. Hou, Y., Chao, Y., Tung, H., Wang, H. \& Shan, Y.: Coexpression of CD44positive/CD133-positive cancer stem cells and CD204-positive tumor-associated macrophages is a predictor of survival in pancreatic ductal adenocarcinoma. Cancer 2014,120:2766-2777.

16. Medrek, C., Pontén, F., Jirström, K. \& Leandersson, K.: The presence of tumor associated macrophages in tumor stroma as a prognostic marker for breast cancer patients. BMC Cancer 2012,12:306.

17. Platonova, S., Cherfils-Vicini, J., Damotte, D., Crozet, L., Vieillard, V., Validire, P., André, P., Dieu-Nosjean, M., Alifano, M., Régnard, J. et al.: Profound coordinated alterations of intratumoral NK cell phenotype and function in lung carcinoma. Cancer Res 2011,71:5412-5422.

18. Takeuchi, H., Maehara, Y., Tokunaga, E., Koga, T., Kakeji, Y. \& Sugimachi, K.: Prognostic significance of natural killer cell activity in patients with gastric carcinoma: a multivariate analysis. Am J Gastroenterol 2001,96:574-578.

19. Rusakiewicz, S., Semeraro, M., Sarabi, M., Desbois, M., Locher, C., Mendez, R., Vimond, N., Concha, A., Garrido, F., Isambert, N. et al.: Immune infiltrates are prognostic factors in localized gastrointestinal stromal tumors. Cancer Res 2013,73:3499-3510. 
20. Taketomi, A., Shimada, M., Shirabe, K., Kajiyama, K., Gion, T. \& Sugimachi, K.: Natural killer cell activity in patients with hepatocellular carcinoma: a new prognostic indicator after hepatectomy. Cancer 1998,83:58-63.

21. Nakano, O., Sato, M., Naito, Y., Suzuki, K., Orikasa, S., Aizawa, M., Suzuki, Y., Shintaku, I., Nagura, H. \& Ohtani, H.: Proliferative activity of intratumoral CD8(+) Tlymphocytes as a prognostic factor in human renal cell carcinoma: clinicopathologic demonstration of antitumor immunity. Cancer Res 2001,61:5132-5136.

22. Scott, D.W., Chan, F.C., Hong, F., Rogic, S., Tan, K.L., Meissner, B., Ben-Neriah, S., Boyle, M., Kridel, R., Telenius, A. et al.: Gene expression-based model using formalinfixed paraffin-embedded biopsies predicts overall survival in advanced-stage classical Hodgkin lymphoma. J Clin Oncol 2013,31:692-700.

23. Whelchel, J.C., Farah, S.E., McLean, I.W. \& Burnier, M.N.: Immunohistochemistry of infiltrating lymphocytes in uveal malignant melanoma. Invest Ophthalmol Vis Sci 1993,34:2603-2606.

24. Giraldo, N.A., Becht, E., Pagès, F., Skliris, G., Verkarre, V., Vano, Y., Mejean, A., SaintAubert, N., Lacroix, L., Natario, I. et al.: Orchestration and Prognostic Significance of Immune Checkpoints in the Microenvironment of Primary and Metastatic Renal Cell Cancer. Clin Cancer Res 2015,21:3031-3040.

25. Remark, R., Alifano, M., Cremer, I., Lupo, A., Dieu-Nosjean, M., Riquet, M., Crozet, L., Ouakrim, H., Goc, J., Cazes, A. et al.: Characteristics and clinical impacts of the immune environments in colorectal and renal cell carcinoma lung metastases: influence of tumor origin. Clin Cancer Res 2013,19:4079-4091.

26. Taube, J.M., Anders, R.A., Young, G.D., Xu, H., Sharma, R., McMiller, T.L., Chen, S., Klein, A.P., Pardoll, D.M., Topalian, S.L. et al.: Colocalization of inflammatory response with B7-h1 expression in human melanocytic lesions supports an adaptive resistance mechanism of immune escape. Sci Transl Med 2012,4:127ra37.

27. Hanahan, D. \& Weinberg, R.A.: Hallmarks of cancer: the next generation. Cell 2011,144:646-674.

28. Dunn, G.P., Old, L.J. \& Schreiber, R.D.: The immunobiology of cancer immunosurveillance and immunoediting. Immunity 2004,21:137-148.

29. Dienstmann, R., Guinney, J., Delorenzi, M., de Reynies, A., Roepman, P., Sadanandam, A., Vermeulen, L., Schlicker, A., Missiaglia, E., Soneson, C. et al.: Colorectal Cancer Subtyping Consortium (CRCSC) identification of a consensus of molecular subtypes.. J Clin Oncol 2014,32:5s.

30. Becht, E., Giraldo, N.A., Beuselinck, B., Job, S., Marisa, L., Vano, Y., Oudard, S., Zucman-Rossi, J., Laurent-Puig, P. \& Sautès-Fridman, C.: Prognostic and theranostic impact of molecular subtypes and immune classifications in Renal Cell Cancer (RCC) and Colorectal Cancer (CRC). Oncoimmunology 2015,4:12:. 
31. Beuselinck, B., Job, S., Becht, E., Karadimou, A., Verkarre, V., Couchy, G., Giraldo, N., Rioux-Leclercq, N., Molinié, $V$., Sibony, M. et al.: Molecular subtypes of clear cell renal cell carcinoma are associated with sunitinib response in the metastatic setting. Clin Cancer Res 2015,21:1329-1339.

32. Le, D.T., Uram, J.N., Wang, H., Bartlett, B.R., Kemberling, H., Eyring, A.D., Skora, A.D., Luber, B.S., Azad, N.S., Laheru, D. et al.: PD-1 Blockade in Tumors with Mismatch-Repair Deficiency. N Engl J Med 2015,372:2509-2520.

33. Rizvi, N.A., Hellmann, M.D., Snyder, A., Kvistborg, P., Makarov, V., Havel, J.J., Lee, W., Yuan, J., Wong, P., Ho, T.S. et al.: Cancer immunology. Mutational landscape determines sensitivity to PD-1 blockade in non-small cell lung cancer. Science 2015,348:124-128.

34. Tumeh, P.C., Harview, C.L., Yearley, J.H., Shintaku, I.P., Taylor, E.J.M., Robert, L., Chmielowski, B., Spasic, M., Henry, G., Ciobanu, V. et al.: PD-1 blockade induces responses by inhibiting adaptive immune resistance. Nature 2014,515:568-571.

35. Maldonado, L., Teague, J.E., Morrow, M.P., Jotova, I., Wu, T.C., Wang, C., Desmarais, C., Boyer, J.D., Tycko, B., Robins, H.S. et al.: Intramuscular therapeutic vaccination targeting HPV16 induces $\mathrm{T}$ cell responses that localize in mucosal lesions. Sci Transl Med 2014,6:221ra13.

36. Lutz, E.R., Wu, A.A., Bigelow, E., Sharma, R., Mo, G., Soares, K., Solt, S., Dorman, A., Wamwea, A., Yager, A. et al.: Immunotherapy converts nonimmunogenic pancreatic tumors into immunogenic foci of immune regulation. Cancer Immunol Res 2014,2:616-631.

37. Taube, J.M., Klein, A., Brahmer, J.R., Xu, H., Pan, X., Kim, J.H., Chen, L., Pardoll, D.M., Topalian, S.L. \& Anders, R.A.: Association of PD-1, PD-1 Ligands, and Other Features of the Tumor Immune Microenvironment with Response to Anti-PD-1 Therapy. Clin Cancer Res 2014,20:5064-5074.

38. Powles, T., Eder, J.P., Fine, G.D., Braiteh, F.S., Loriot, Y., Cruz, C., Bellmunt, J., Burris, H.A., Petrylak, D.P., Teng, S. et al.: MPDL3280A (anti-PD-L1) treatment leads to clinical activity in metastatic bladder cancer. Nature 2014,515:558-562.

39. Giraldo, N.A., Becht, E., Remark, R., Damotte, D., Sautès-Fridman, C. \& Fridman, W.H.: The immune contexture of primary and metastatic human tumours. Curr Opin Immunol 2014,27:8-15.

40. Deligne, C., Metidji, A., Fridman, W. \& Teillaud, J.: Anti-CD20 therapy induces a memory Th1 response through the IFN- $\gamma / \mathrm{IL}-12$ axis and prevents protumor regulatory T-cell expansion in mice. Leukemia 2015,29:947-957.

41. Mortenson, E.D. \& Fu, Y.: Adaptive Immune Responses and HER2/neu Positive Breast Cancer. Curr Pathobiol Rep 2013,1:37-42. 
[1] * A review on the impact of the immune contexture in various cancers

[3] * A demonstration that $\mathrm{CD}^{+}{ }^{+} \mathrm{T}$ cells densities correlate with favorable outcome in a human cancer

[4] ** The demonstration of the role of the density, location and functional orientation of $\mathrm{T}$ cells in controlling the outcome of a human cancer

[6] ** A comprehensive analysis of the immune contexture in colorectal cancers depicting the clinical impact of all immune cell populations, their locations, functional orientations and their relationship with cancer stage

[7] * The first demonstration of the clinical impact of TLS in cancer patients

[8] * The demonstration that TLS shape intratumor CD8+ $\mathrm{T}$ cell responses

[9] * The demonstration that intratumor B lymphocytes produce anti-tumor antibodies

$[10] *$ A comprehensive review of the role of TLS in cancers

[27] * The analysis of the impact of components of the immune contexture in the shaping an efficient or deleterious anti-tumor immune reaction

$[28] *$ A demonstration of the clinical impact of the immune contexture in metastatic cancer sites

[35] ** A clinical trial demonstrating that inhibition of immune checkpoint results in longer survival in colorectal-cancer patients with hypermutated MSI tumors 
Highly vascularized Abundant Fibroblasts

IL-1, IL-6 and TNF-a TGF-B and VEGF

Immature DC
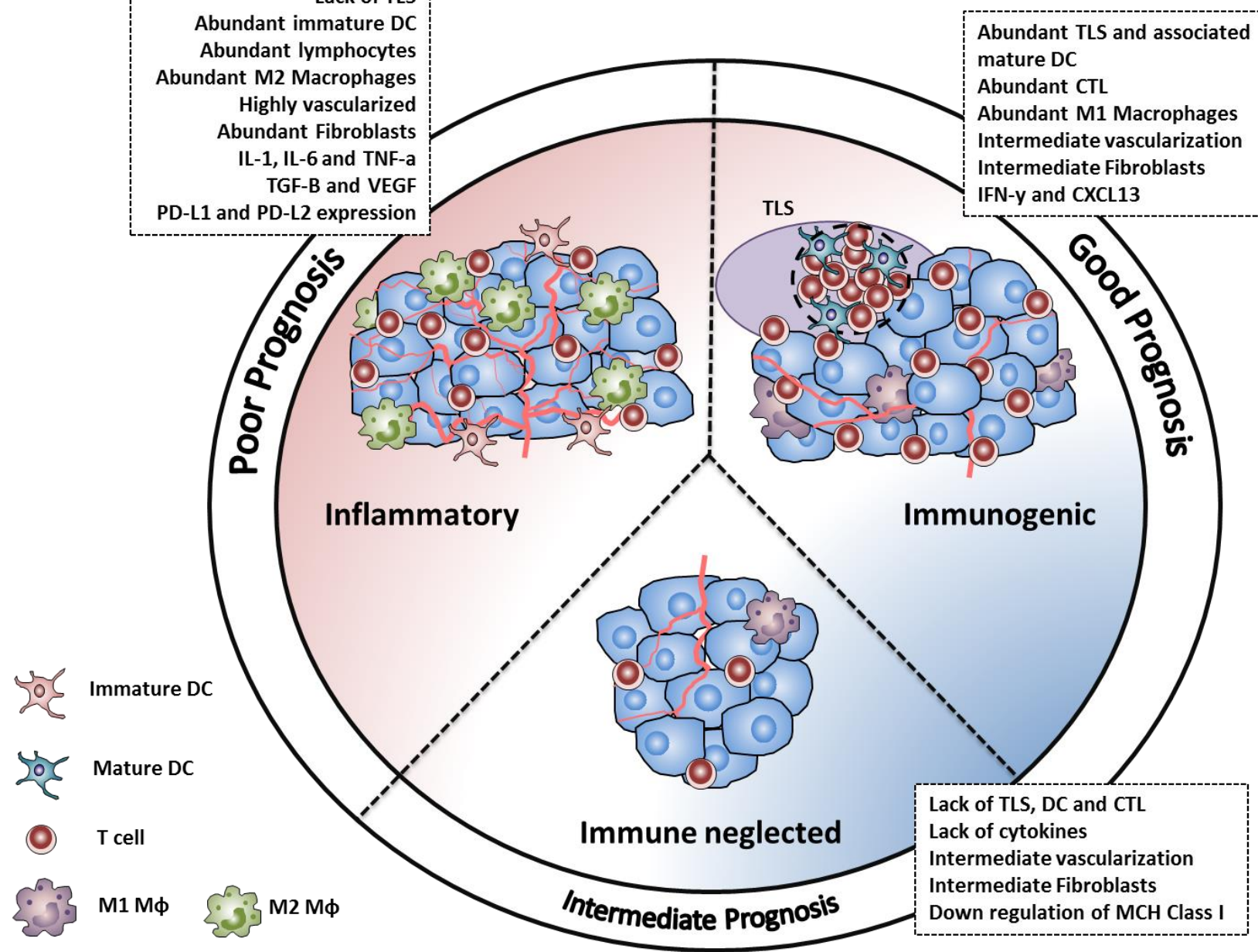

Abundant TLS and associated mature DC Abundant CTL Abundant M1 Macrophages Intermediate vascularization Intermediate Fibroblasts IFN-y and CXCL13

Figure 1.

The immunological wheel. Cartoon depicting the three immune contextures than can be induced in tumors. The 'immunogenic tumors' are characterized by abundant Cytotoxic T-Lymphocyte (CTL) infiltration, the presence of Tertiary Lymphoid Structures (TLS) and low/moderate vascularization while associated with the longest patient's survival. The 'immune neglected' tumors are characterized by lack of infiltration by immune cells, low/moderate vascularization and intermediate prognosis. Finally, the 'inflammatory tumors' are characterized by abundant CTL in the absence of TLS, conspicuous infiltration with M2 macrophages, severe vascularization and poor prognosis. 


\begin{tabular}{|c|c|c|c|c|c|}
\hline $\begin{array}{l}\text { Immune } \\
\text { subgroup }\end{array}$ & $\begin{array}{l}\text { Examples of } \\
\text { corresponding } \\
\text { molecular } \\
\text { subgroups }\end{array}$ & $\begin{array}{l}\text { Microenvironment } \\
\text { characteristics }\end{array}$ & $\begin{array}{c}\text { Escape } \\
\text { mechanisms }\end{array}$ & $\begin{array}{c}\text { Immunotherapeutic } \\
\text { goals }\end{array}$ & $\begin{array}{c}\text { Potential } \\
\text { immunotherapeutic } \\
\text { approach }\end{array}$ \\
\hline Immunogenic & $\begin{array}{c}\text { CRC } \\
\text { Hypermutated }\end{array}$ & $\begin{array}{l}\text { High T cell } \\
\text { infiltration } \\
\text { with Th1 } \\
\text { orientation } \\
\text { and cytotoxic } \\
\text { lymphocytes }\end{array}$ & $\begin{array}{c}\text { Immune } \\
\text { checkpoints : } \\
\text { PD1 axis, } \\
\text { LAG3, CTLA4 }\end{array}$ & $\begin{array}{l}\text { Boost intratumor } \\
\text { cytotoxic T cells }\end{array}$ & Checkpoint-blockade \\
\hline Inflammatory & $\begin{array}{c}\text { CRC } \\
\text { Mesenchymal } \\
\text { ccrcc4 }\end{array}$ & $\begin{array}{l}\text { High lymphocyte } \\
\text { and myeloid cells } \\
\text { infiltration } \\
\text { High angiogenesis } \\
\text { Stromal } \\
\text { mesenchymal cells }\end{array}$ & $\begin{array}{l}\text { Hypoxia } \\
\text { TGFß } \\
\text { PD1 axis }\end{array}$ & \begin{tabular}{|} 
Dampen inflammation \\
and associated \\
suppressive \\
mechanisms \\
Establish normoxia \\
Boost intratumor \\
suppressed cytotoxic T \\
cells
\end{tabular} & $\begin{array}{c}\text { Anti-angiogenic } \\
\text { Anti TGF } \beta \\
\text { Checkpoint-blockade }\end{array}$ \\
\hline $\begin{array}{l}\text { Immune } \\
\text { neglected }\end{array}$ & $\begin{array}{l}\text { CRC Canonical } \\
\text { and Metabolic } \\
\text { ccrcc1 and } \\
\text { ccrcc2 }\end{array}$ & $\begin{array}{l}\text { Low lymphocytic } \\
\text { and myeloid cells } \\
\text { infiltration }\end{array}$ & $\begin{array}{l}\text { Low class I } \\
\text { MHC } \\
\text { expression }\end{array}$ & $\begin{array}{l}\text { Attract cytotoxic T } \\
\text { cells in tumors } \\
\text { Bypass class I MHC } \\
\text { presentation }\end{array}$ & $\begin{array}{c}\text { CAR T cells } \\
\text { Bi-specific antibodies }\end{array}$ \\
\hline
\end{tabular}

434 Table 1.

435 Immunotherapeutic approaches tailored for tumor immune subgroups.

436 The three immune subgroups, their hallmarks, immune escape mechanisms are listed, 437 as well as the corresponding immunotherapeutic goals and potential approaches.

$438 \quad$ CRC : Colorectal cancer

ccrcc : clear-cell Renal Cell Carcinoma 
441 Financial support: This work was supported by the 'Institut National de la

442 Santé et de la Recherche Médicale', the University Paris-Descartes, the

443 University Pierre et Marie Curie, the Institut National du Cancer (2009-1-

444 PLBIO-07-INSERM 6-1，2010-1-PLBIO-03-INSERM 6-1， 2011-1-PLBIO-06-

445 INSERM 6-1), CARPEM (CAncer Research for PErsonalized Medicine), Labex

446 Immuno-Oncology (LAXE62_9UMS872 FRIDMAN, 11LAXE62_9UMS872

447 FRIDMAN), ans the Fondation ARC pour la Rercherche sur le Cancer 448 (SL220110603483), the Universidad de los Andes School of Medicine, 449 Colciencias (NAG). EB is supported by CARPEM post-doctorate fellowship and 450 NAG by PPATH doctorate fellowship.

451 Acknowledgements: We thank the members of the teams of I. Cremer/J.L. 452 Teillaud and J. Galon at the Cordeliers Research Center for their fruitful 453 discussions and who performed most of the work cited in this review. 